\title{
Estimation of Crop Water Requirements in Irrigated Land of the Khorezm Oasis in the Context of Climate Change
}

\author{
Stulina Galina ${ }^{1}$, Solodkiy Georgy ${ }^{1}$ \& Eshtchanov Odilbek $^{1}$ \\ ${ }^{1}$ Interstate Coordination Water Commission Scientific - Information Center SIC ICWC, Tashkent, Uzbekistan \\ Correspondence: Stulina Galina, Interstate Coordination Water Commission Scientific - Information Center SIC \\ ICWC, Tashkent, Uzbekistan. E-mail: galina_stulina@mail.ru
}

\author{
Received: September 7, 2018 Accepted: September 21, 2018 Online Published: January 25, 2018 \\ doi:10.5539/sar.v8n1p94 \\ URL: https://doi.org/10.5539/sar.v8n1p94
}

\begin{abstract}
Khorezm province is located in the northwest part of Uzbekistan in the basin of one of largest water sources the Amu Darya River - and occupies the left bank in the Amu Darya lower reaches. The area of the province is $6,100 \mathrm{~km} 2$. The province borders Karakalpakstan in the North, Turkmenistan in the South, and Bukhara province of Uzbekistan in the South-East.

Uzbekistan is situated in the territory, where high rates of climate change are expected and observed. According to forecasts, further climate change would cause even higher air temperatures, altered precipitation patterns and severe and prolonged droughts, with consequent lowering of available water resources. More plausible scenarios for Uzbekistan suggest more than $4^{\circ} \mathrm{C}$ rise in average annual air temperatures by 2080 . Water discharge along the Amu Darya River is expected to decrease potentially by $10-15 \%$.

Objective of given work is to analyze and assess the positive impacts of climate change through alterations of bioclimatic potential in given terrain and agromelioration parameters of crops, with consequent changes in crop water requirements.

Earlier research results showed that the observed growth of thermal potential allows earlier sowing and more rapid accumulation of effective temperatures. This will shorten plant development phases, on the one hand, and, as a result, reduce water use by crops, on the other hand.
\end{abstract}

Keywords: Khorezm, Uzbekistan, climate change, agricultural, adaptation, water requirements

\section{Introduction}

Uzbekistan is exposed heavily to climate change threats. The UzHydromet (Chub, 2007) forecasts that climate change would further lead to rising temperatures, changes in precipitation patterns, and more severe and prolonged droughts, with consequent worsening of water availability. The most probable scenarios for Uzbekistan imply the rise in average annual temperature by more than $4^{\circ} \mathrm{C}$ by 2080 . It is predicted (Dukhovniy, 2008 ) that the flow may decrease by $2-3 \%$ in the Syrdarya Basin and by $10-15 \%$ in the Amudarya Basin. Hence, there is a need for serious efforts to be made for adaptation to climate change and mitigation of risks.

Present research was carried out as part of the LaVaCCA Project entitled, "Assessing Land Value Changes and Developing a Discussion-Support-Tool for Improved Land Use Planning in the Irrigated Lowlands of Central Asia" supported by Volkswagen Foundation. This work is a follow-up of multi-year author's research on climate change and adaptation (Stulina \& Madramootoo, 2005; Stulina \& Usmanov, 2002; Stulina \& Solodkiy, 2011).

\section{Research Object}

Khorezm province (Figure 1) is located in the northwest part of Uzbekistan and occupies the left bank in the Amudarya lower reaches.

The area of the province is $6,100 \mathrm{~km}^{2}$. The province borders Karakalpakstan in the north, Turkmenistan in the south, and Bukhara province in Uzbekistan in the southeast.

Major irrigation sources in the province are the Amudarya River and diversion canals (Shavat, Kulavat, Gazawat).

Water management is under responsibility of four Irrigation System Administrations (ISA): Shavat-Kulawat, 
Karamazy-Klychbai, Tashsaka, and Palvan-Gazawat.

The inter-farm network management is assigned to WUA that serve (as of 2014) 4755 water users.

The climate is sharply continental, with the summer temperature reaching $+45^{\circ} \mathrm{C}$ and the winter temperature falling down to $-32^{\circ} \mathrm{C}$. Given thin snow cover, the soil freezes down to half a meter.

Shallow saline groundwater $(0-1 \mathrm{~m})$ causes salinization over the vast area.

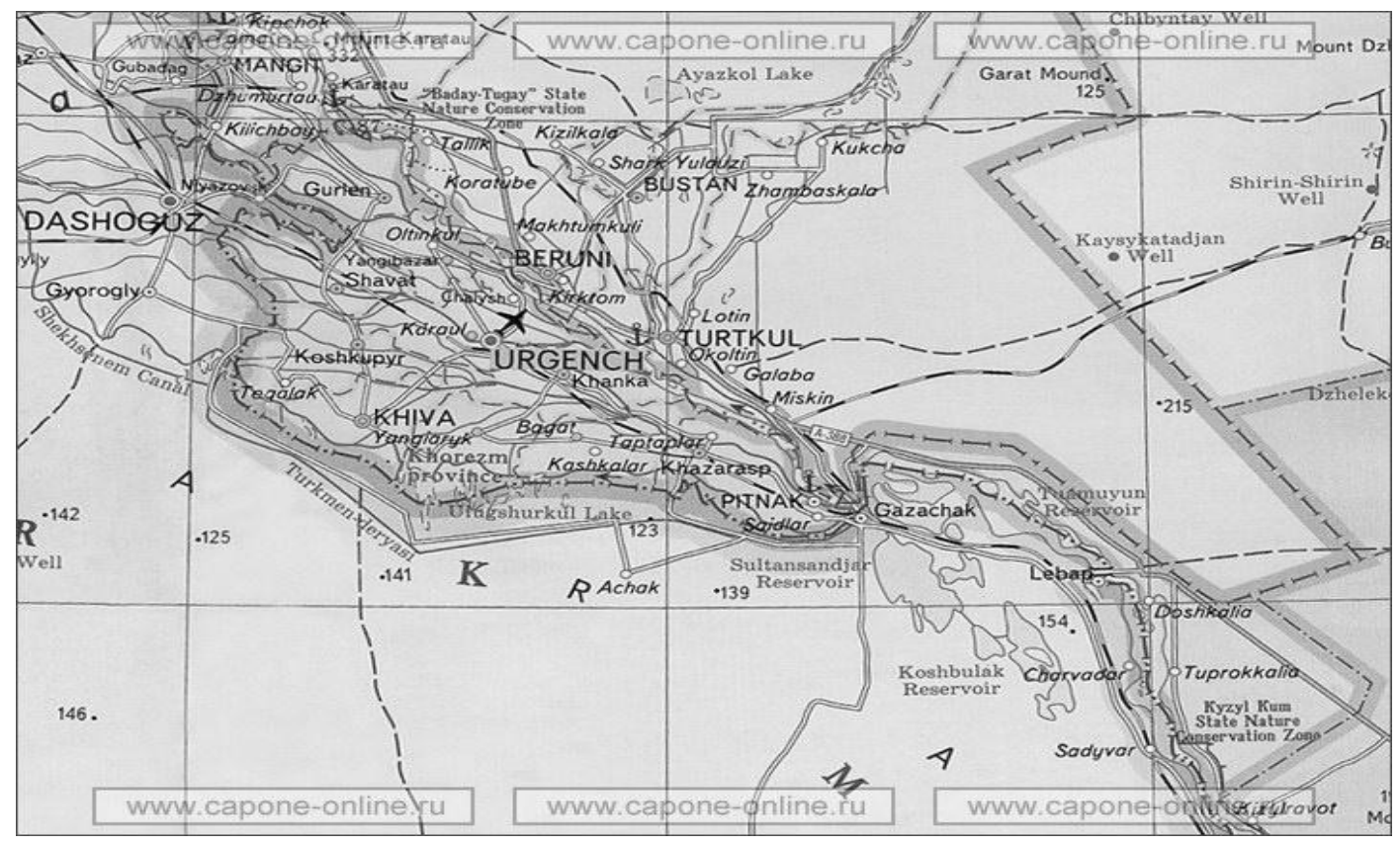

Figure 1. Uzbekistan, Khorezm province

Agriculture is the main economic activity in the province, and almost $80 \%$ of provincial population lives in the rural area.

Cropping patterns are shaped by natural-climatic conditions. The territory of the province is adjacent to the northern boundary of land where cotton can be grown. Shallow groundwater forms hydromorphic soil, which is favorable for rice cultivation. Cucurbits, such as melon and water melon are also common there.

\section{Research Methods}

Water requirements were modeled using the REQWAT model (Stulina \& Usmanov, 2002) developed on the basis of the CROPWAT model, which underwent certain modifications. The main difference from the CROPWAT is the module of groundwater contribution.

Climate data, a soil map, a groundwater well location map and the observations data on groundwater levels for a series of years are used as input for the calculations. The results are displayed in form of ten-day or monthly crop water requirements averaged for the studied area or as maps of annual crop water requirements for various crops.

The REMO model (Mannig et al., 2013; Parry et al., 2007; Parry et al., 1999; Rozenzweig et al., 2001; Vleck et al., 2004) was used for the forecasts of climate change. This climatic model is based on the ECHAM 5 model developed at the Max Plank Institute (Germany). That is the model of global atmosphere circulation. It is used for calculation of global and regional patterns of climate change. The A1B scenario of average warming as a result of greenhouse gas emission was played in the model. Given model allowed constructing the artificial temperature and rainfall series until 2080.

\section{Research Results}

\subsection{Analysis of an Impact of Climate Change}

\subsubsection{Cropping Patterns and Crop Yields}

As mentioned above, the main crops grown in the Khorezm province are cotton (35-45\%), rice (2-18\%), wheat $(0-16 \%)$, and the rest comprises forage crops (3-26\%), cucurbits (1-2\%), and vegetables (3-6\%). Homestead 
plots also cover a large area (12-18\%). Changes in the cropping patterns are caused by certain socio-economic and climatic reasons.

With the adoption of the food security doctrine, the wheat areas extended significantly by integrating wheat into the crop rotation. (Figure 2, Figure 3).

Unfortunately, the expansion of wheat area by $15 \%$ from 1980 till 2012 was accompanied by $19 \%$ reduction of the forage area (Figure 2, Figure 3).

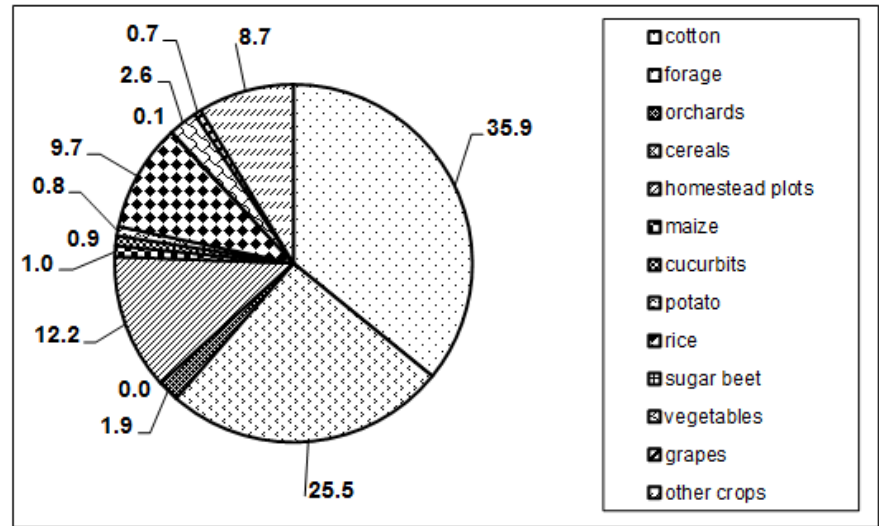

Figure 2. Cropping pattern in the Khorezm province, 1980

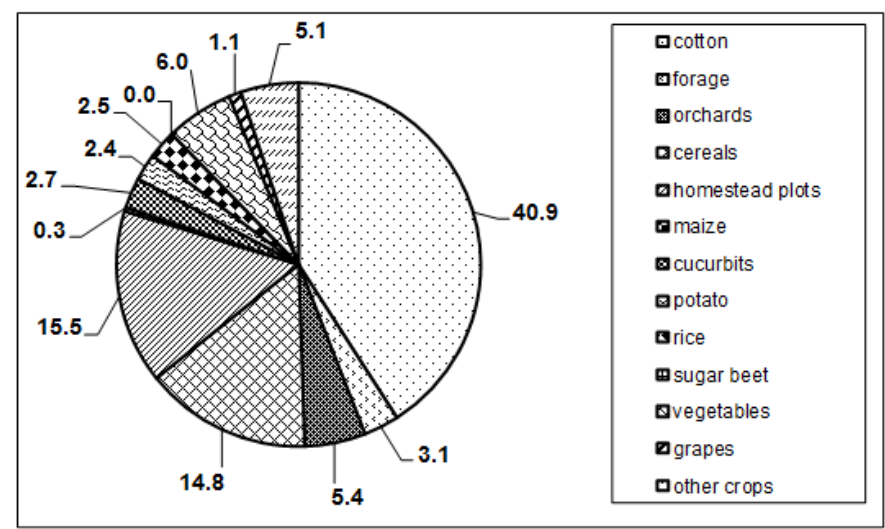

Figure 3. Cropping pattern in the Khorezm province, 2012

In the context of climate change, crop area and yield depend on hydrological situation during a year.

First, this affects rice production, which directly depends on annual water use plan.

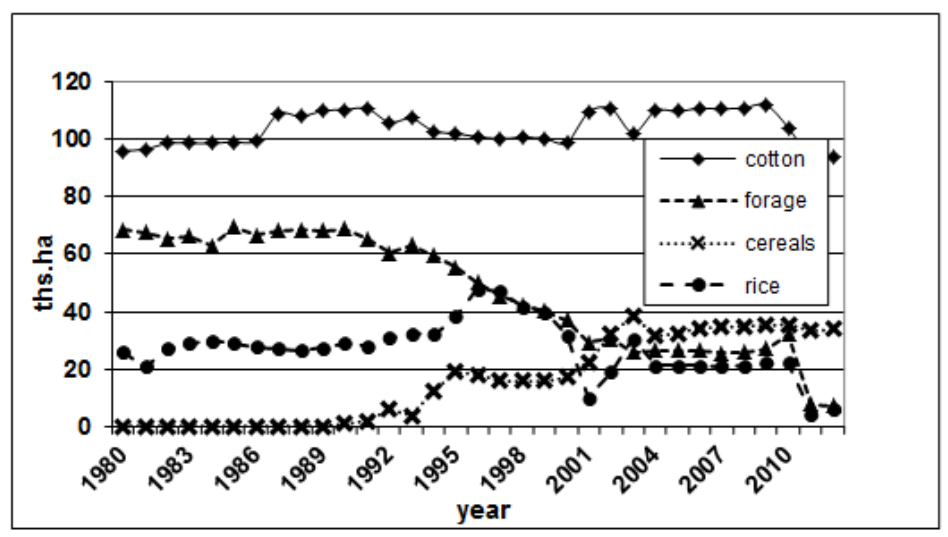

Figure 4. Cropping patterns in the Khorezm province 
Critical decrease in the rice area (Figure 4) is observed in very dry years 2001 and 2011. Graph in Figure 5 demonstrates changes in crop yield by year and the relationship between the yield and climate.

The main crops in Khorezm, such as cotton, rice, forage crops, and wheat show certain reduction of yield, including cotton in 1984, rice in 2000-2002, and wheat in 2003.

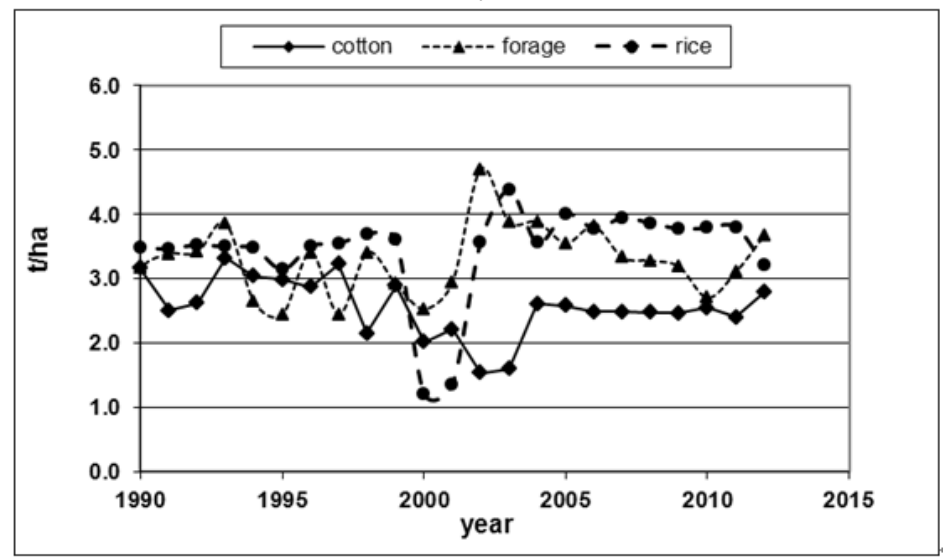

Figure 5. Yields of main crops in the Khorezm province

Those years, the reductions in yields were $30 \%$ for cotton, $13 \%$ for wheat, $65 \%$ for rice, and $20 \%$ for forage crops against the average yields over the last 30 years.

\subsubsection{Crop Water Requirements}

Water delivery per irrigated hectare also depends on climatic conditions.

Water availability dramatically drops during dry years. Figure 6 shows the catastrophic water situation in the years of drought, when water delivery decreased from 4,000 million $\mathrm{m}^{3}$ to 900 million $\mathrm{m}^{3}$. The decrease in unit water delivery in $\mathrm{m}^{3} / \mathrm{t}$ is a result of reduction of the total available water (Figure 6) and the cause of lowering yields (Figure 5).

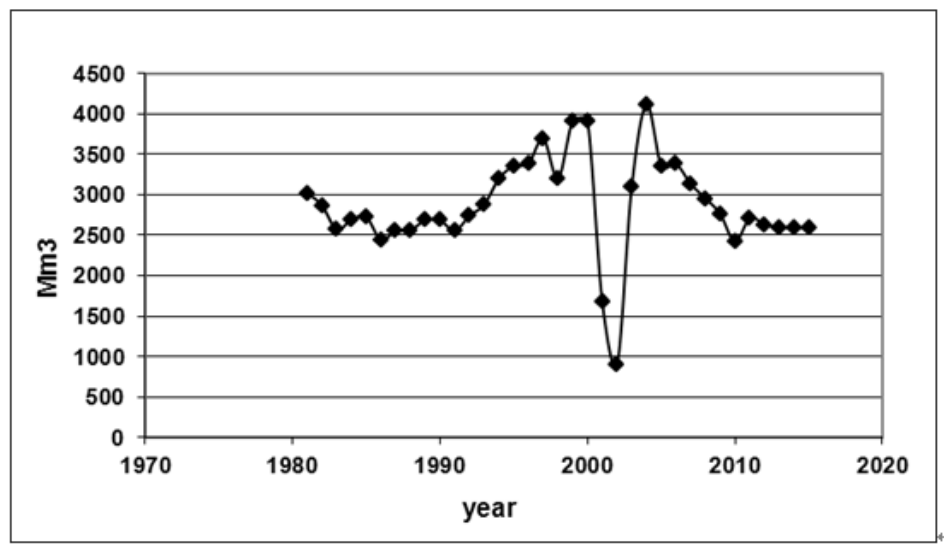

Figure 6. Agricultural water use

\section{Climate Change and Adaptation}

\subsection{Assessment of Thermal Resources and Their Forecast}

The Khorezm oasis situated in the north of the Republic refers to the cool thermal zone, with the sum of effective temperatures as $1000-2800^{\circ} \mathrm{C}$, according to Babushkin's classification (Babushkin, 1974). The thermal capacity is estimated through the sum of effective temperatures. The effective temperature is the difference between the mean daily temperature and the temperature at which development of any crop starts. This threshold temperature is specific for each crop (Table 1). 
Table 1. Minimum (1), optimal (2) and maximum (3) air temperature by crop development phase

\begin{tabular}{llll}
\hline \multirow{2}{*}{ Crop } & \multicolumn{3}{l}{ Sowing } \\
\cline { 2 - 4 } & 1 & 2 & 3 \\
\hline Cotton & 10 & $12-14$ & - \\
Rice & $10-12$ & $20-25$ & $30-32$ \\
Maize & $7-8$ & $10-12$ & $30-32$ \\
Winter wheat & $10-12$ & $15-18$ & $18-20$ \\
\hline
\end{tabular}

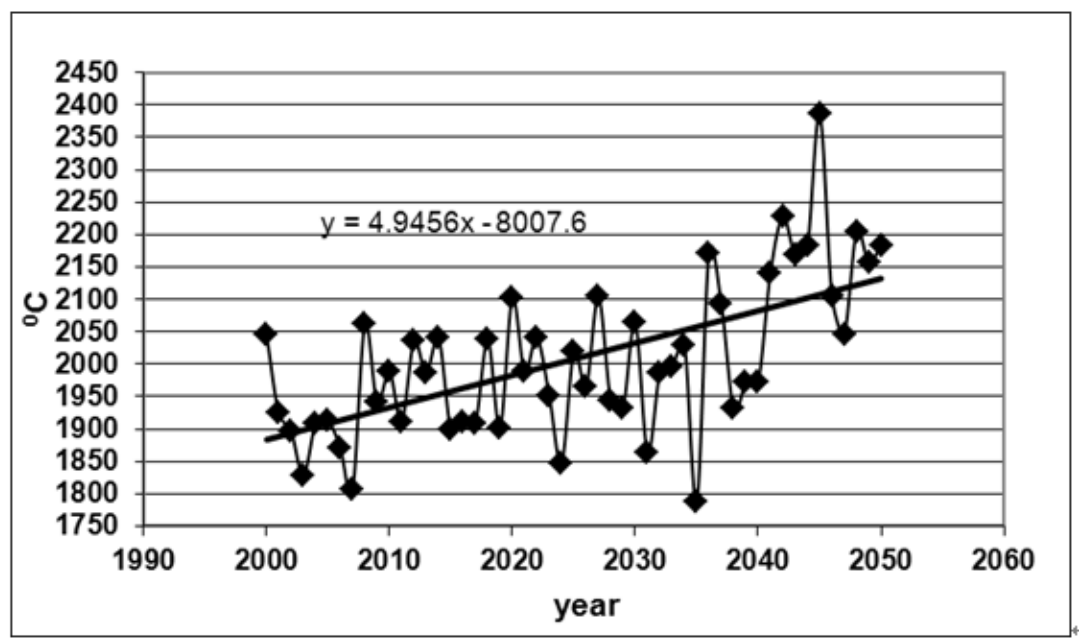

Figure 7. Annual sum of effective temperatures higher than 10 degrees, Khorezm planning zone

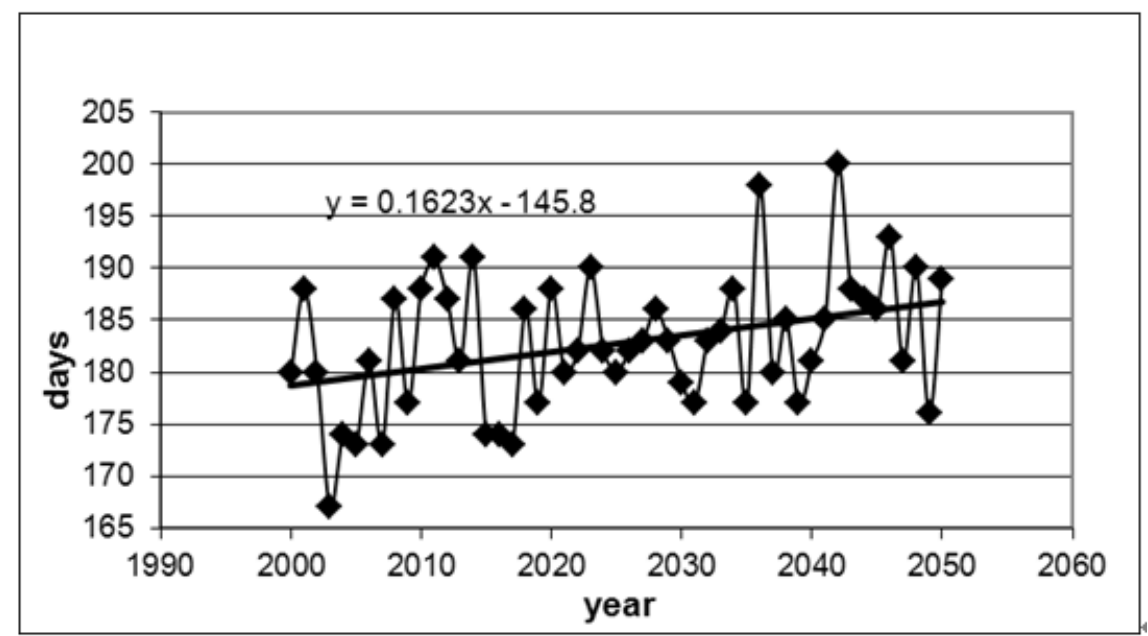

Figure 8 . Number of days in a year with the temperature above 10 degrees, Khorezm planning zone

The analysis of data indicates to steady upward trend of thermal capacity in the area under consideration.

Number of days with the effective temperature above 10 degrees increases to 200 days in some of years, as estimated in the REMO model. The sum of effective temperatures above $10{ }^{\circ} \mathrm{C}$ (Figure 7, Figure 8 ) will increase by $3 \%$ in $2010-2020,11 \%$ in $2020-2030$ and $8 \%$ in $2030-2050$.

The increase in thermal resources reduces the risks for growing of heat-loving crops, such as cotton.

\subsection{Changes in the Date of Steady Temperature Transition}

It is clearly observed that the time suitable for sowing comes earlier. In the REMO scenarios, as compared to the base scenario, steady transition of air temperature through $10{ }^{\circ} \mathrm{C}$ is 4 days earlier and closer to winter and 2 days in the last days of the growing season by 2030, 3 days earlier by 2050, and 6 days earlier in spring season by 2080 (Figure 9). 


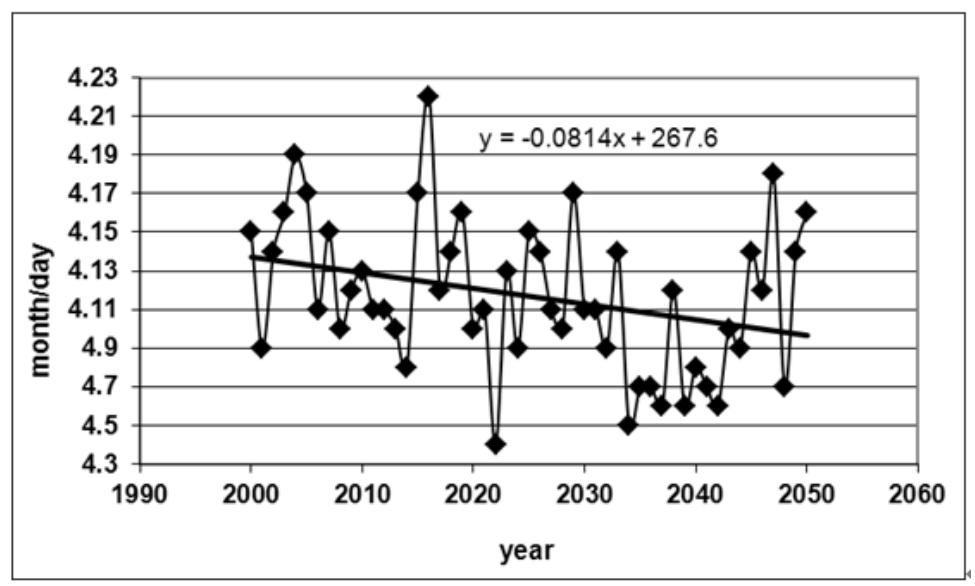

Figure 9. Changes in the dates of steady transition through $10^{\circ} \mathrm{C}$, Khorezm

\subsection{Length of Crop Growing Season}

Thermal resources are to provide annual ripening of different crop varieties cultivated in the region.

The climate change and temperature rise will lead to shift in the time of accumulation of the total effective temperature, which is necessary for ripening of crops.

Table 2 shows the sums of effective temperatures needed for plant development phases and for complete ripening till harvesting.

Table 2. Sums of effective temperatures above $10^{\circ}$ by crop development phase under appropriate soil moisture conditions

\begin{tabular}{llllll}
\hline Variety & $\begin{array}{l}\text { Sowing } \\
\text {-sprouting }\end{array}$ & $\begin{array}{l}\text { Sprouting- } \\
\text { budding }\end{array}$ & $\begin{array}{l}\text { Budding- } \\
\text { flowering }\end{array}$ & $\begin{array}{l}\text { Flowering-opening } \\
\text { of first cotton bolls }\end{array}$ & $\begin{array}{l}\text { Sowing-opening of first } \\
\text { cotton bolls }\end{array}$ \\
\hline $\begin{array}{l}\text { Early } \\
\text { ripening }\end{array}$ & 95 & 400 & 480 & 760 & 1735 \\
Mid-season & 100 & 425 & 500 & 850 & 1875 \\
Late season & 100 & 480 & 530 & 1050 & 2160 \\
\hline
\end{tabular}

The comparison of historical data with REMO simulations indicates to future changes in processes of plant growth and development. Subsequently, this will entail modification of the whole agronomic cycle.

There are 4 phases of plant development, which are described below (Table 3).

Table 3. Description of plant development phases

\begin{tabular}{lrl}
\hline I-phase & P-1 & $\begin{array}{l}\text { starting with sowing, sprouting till formation of cotyledonous leaves and, probably, two or } \\
\text { three full-fledged leaves; soil surface is not covered or slightly covered with plants (canopy is } \\
\text { less than 10\%) }\end{array}$ \\
\hline II-phase & P-2 & $\begin{array}{l}\text { crop development (from the beginning of quick growth till blossoming, when the rate of } \\
\text { development slows down; by the end of the phase canopy is 70-80\%), }\end{array}$ \\
\hline III-phase & P-3 & $\begin{array}{l}\text { flowering or mid-season phase (includes the main period of blossoming and early phase of } \\
\text { seed and fruit formation; from effective canopy 70-80\% till start of fading and falling off }\end{array}$ \\
\hline IV-phase & P-4 & ripening (when crop develops, ripens and harvest is collected) \\
\hline
\end{tabular}

According to this classification and using the sum of effective temperatures needed for each phase to be completed, the length of crop development phases was calculated for main crops and for different years and relevant forecast for the future was made.

The analysis made for cotton demonstrates the results. Figure 10 shows changes in development phases of mid-season cotton, whereas Table 4 shows changes in the length of development phases for early ripening, midand late-season cotton varieties. 


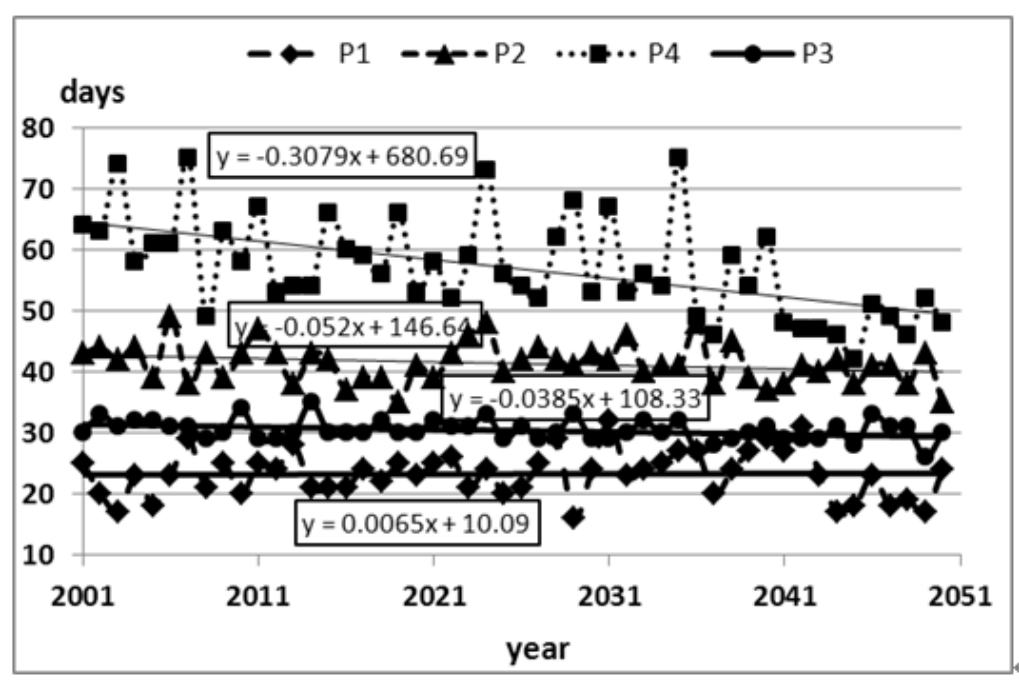

Figure 10. Change in the length of development phases for mid-season cotton, by year

The derived results indicate to shortening of cotton growth season in general and of every phase in particular. The duration of phases considerably changes over the analyzed and forecast period, depending on climate. By 2050, the length of growing season will become 20 days shorter as compared to 2000 for mid-season cotton, 19 days shorter for late-season cotton, and 12 days shorter for early ripening cotton (Figure 11, Figure 12, Figure 13).

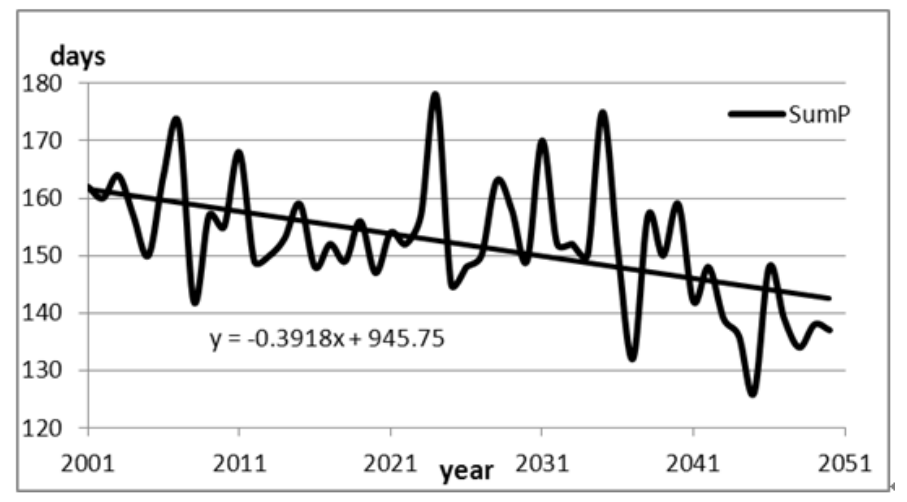

Figure 11. Trend of the length of mid-season cotton growth

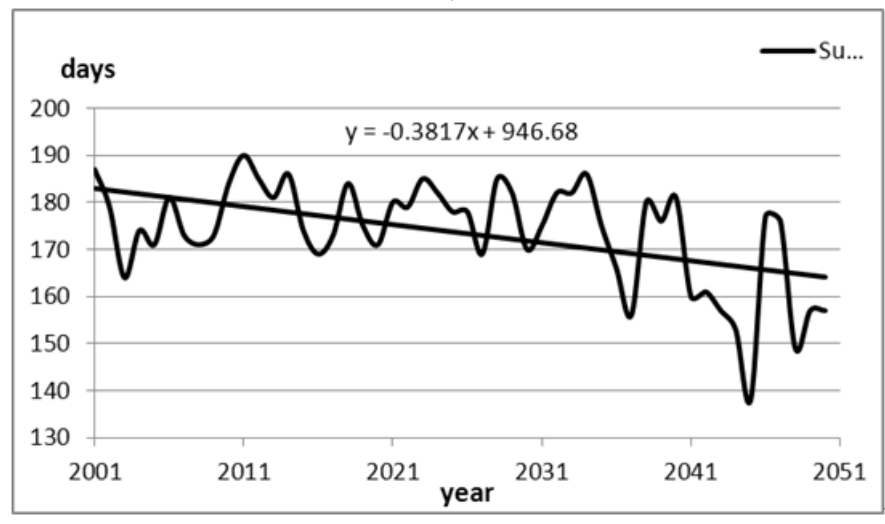

Figure 12. Trend of the length of late-season cotton growth 


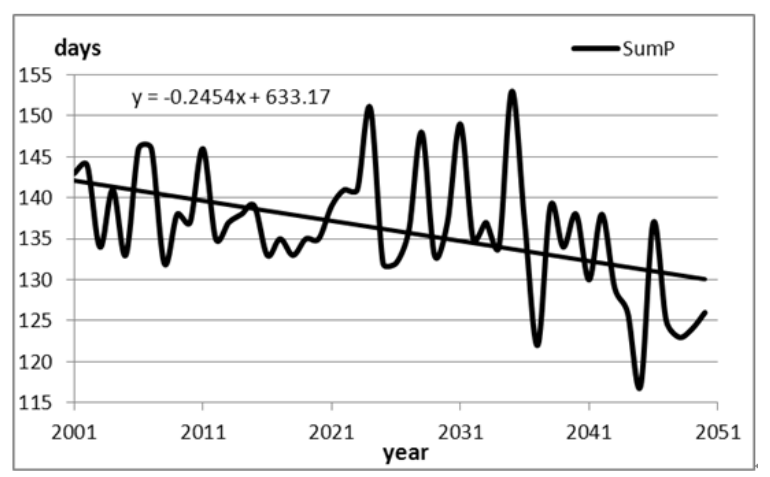

Figure 13. Trend of the length of early ripening cotton growth

Table 4. Change in the length of cotton development phases

\begin{tabular}{lllllll}
\hline \multirow{4}{*}{ Late-season cotton } & Year & P1 & P2 & P3 & P4 & Total \\
\cline { 2 - 6 } & 2000 & 23 & 45 & 35 & 80 & 183 \\
& 2030 & 23 & 44 & 33 & 72 & 172 \\
& 2050 & 23 & 43 & 32 & 66 & 164 \\
& $2030-2000$ & 0 & -2 & -2 & -8 & -11 \\
& $2050-2030$ & 0 & -1 & -1 & -6 & -8 \\
\hline Mid-season cotton & 2000 & 23 & 43 & 31 & 65 & 162 \\
& 2030 & 23 & 41 & 30 & 56 & 150 \\
& 2050 & 23 & 40 & 29 & 49 & 142 \\
& $2030-2000$ & 0 & -2 & -1 & -9 & -12 \\
\hline Early ripening cotton & $2050-2030$ & 0 & -1 & -1 & -6 & -8 \\
\hline & 2000 & 22 & 41 & 28 & 51 & 142 \\
& 2030 & 22 & 39 & 28 & 46 & 135 \\
& 2050 & 22 & 38 & 27 & 43 & 130 \\
& $2030-2000$ & 0 & -1 & -1 & -5 & -7 \\
& $2050-2030$ & 0 & -1 & -1 & -3 & -5 \\
\hline
\end{tabular}

The growing season of most crops becomes shorter as well.

Based on the analysis made above, the temperature rise has a positive effect through acceleration of physiological processes and, thus, shortening of the length of crop development and growth. However, with temperature rise, the risk of extremes affecting adversely agricultural production becomes high. The rise of temperature above critical value will provoke plant stress.

Figures 14, 15 and 16 show the results of water requirement calculations by the REQWAT model using the REMO's climate forecasts, for different cotton varieties. Water requirement trends indicate to lowering of cotton irrigation requirements. However, this takes place only at the expense of shortened growing season of cotton as shown above (Table. 4, Table. 5; Figure 11, Figure 12, Figure 13).

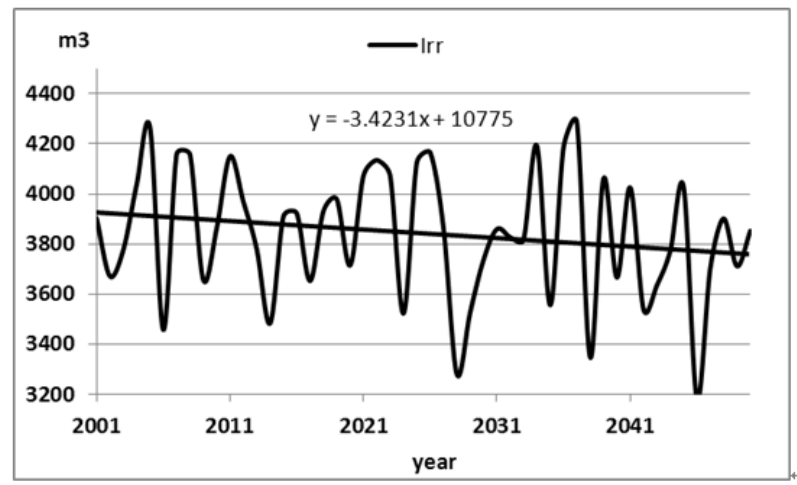

Figure 14. Scenario of changing water requirements of early ripening cotton under climate change 


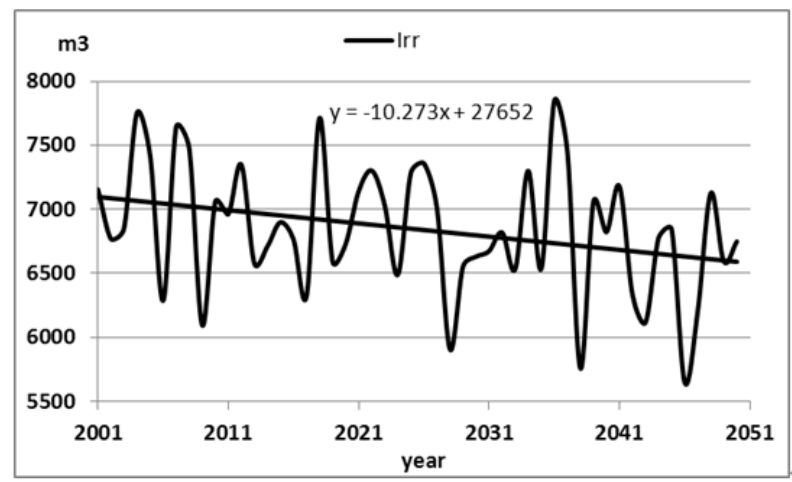

Figure 15. Scenario of changing water requirements of mid-season cotton under climate change

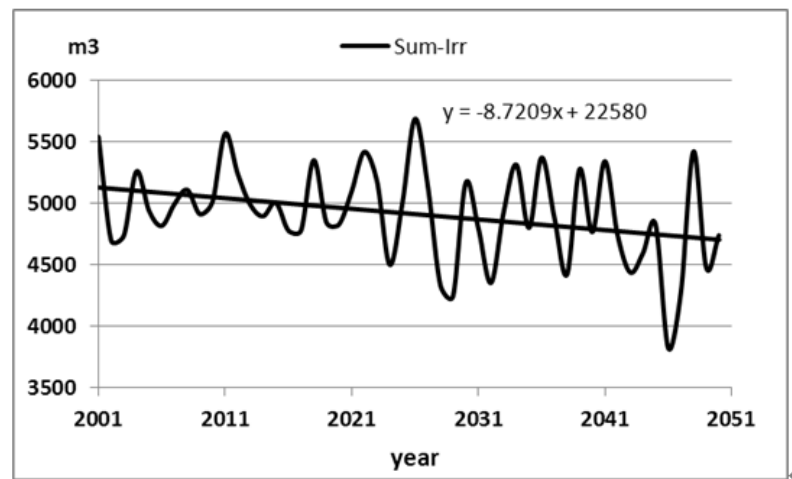

Figure 16. Scenario of changing water requirements of late-season cotton under climate change

For cotton, the growing season would become 30 days shorter and the water use would decrease by more than $100 \mathrm{~mm}$ by 2100 . The thermal pattern should be considered as the basis for crop rotation and, hence, for water planning.

Table 5.

\begin{tabular}{lllll}
\hline Crop & 2001 & 2025 & 2050 & change \\
\hline Pulses & 3474.356 & 3410.9 & 3344.8 & -130 \\
Table grapes & 6152.43 & 6114.75 & 6075.5 & -77 \\
Potato & 4475.223 & 4408.575 & 4339.15 & -136 \\
Maize for corn & 4243.818 & 4167.45 & 4087.9 & -156 \\
Lucerne species & 5644.879 & 5380.856 & 5105.832 & -539 \\
Sunflower & 4029.272 & 4011.8 & 3993.6 & -36 \\
Sugar beet & 7698.01 & 7722.25 & 7747.5 & 49 \\
Sweet melon & 5643.4 & 5317 & 4977 & -666 \\
Pumpkin & 3463.549 & 3380.725 & 3294.45 & -169 \\
Tomato & 7494.43 & 7192.75 & 6878.5 & -616 \\
Water melon & 4113.84 & 3918 & 3714 & -400 \\
Rice & 12670.39 & 12415.75 & 12150.5 & -520 \\
Early rice & 9254.011 & 9014.275 & 8764.55 & -489 \\
Orchards & 3649.051 & 3458.275 & 3259.55 & -390 \\
Pulses as double-season crop & 2320.364 & 2233.1 & 2142.2 & -178 \\
Potato as double-season crop & 3648.572 & 3518.3 & 3382.6 & -266 \\
Beet as double-season crop & 4246.207 & 4203.175 & 4158.35 & -88 \\
Cucurbits as double-season crop & 3227.234 & 3136.85 & 3042.7 & -185 \\
Maize for silage as double-season crop & 3297.493 & 3213.325 & 3125.65 & -172 \\
Early cotton & 3925.577 & 3843.425 & 3757.85 & -168 \\
Mid-season cotton & 7101.73 & 6855.25 & 6598.5 & -503 \\
Late-season cotton & 5131.28 & 4922 & 4704 & -427 \\
\hline
\end{tabular}


When analyzing water requirements of crops, we took into account probable changes in agro-climatic parameters, including corrected sowing dates, dates of crop development phases, related crop coefficients, and total length of growing seasons. The Table above shows the results of assessment of potential changes in crop water requirements in the Khorezm oasis, based on REMO's climate scenarios.

\section{Conclusion}

As a northernmost area, where cotton, the main crop in the region, is produced, the Aral Sea basin lacks sufficiently sustainable conditions for growth and secured yields of cotton everywhere. However, the temperature rise means that the northern territories start showing climate characteristics that are more typical for southward territory, and the area where potentially cotton could be grown extends. More prolonged growing season offers the possibility to have two harvests a year. Accordingly sowing dates will change. Increased temperatures and carbon dioxide concentrations have a positive effect on growth and development of plants. Given that all main inputs, nutrients, water, and pest and disease control are in place, yield potential of some crops becomes higher under climate change. Thus, the changing climate forces agriculturalists to revise farming practices as with the rise in temperature and moisture and the change in river flow, the whole process chain needs to be modified.

\section{References}

Babushkin, L. N. (1974). Regarding climatic characteristics of summer atmospheric drought and hot dry winds in the cotton region of Uzbekistan: Hot dry winds, their origin and control. Tashkent, 59-64.

Chub, V. Y. (2007). Climate change and its impact on hydrometeorological and agroclimatic processes and on water resourses in the Republic of Uzbekistan. Voris-nashriyot, Tashkent.

Dukhovny, V. A. (2008). Regional Model of Integrated Water Resources Management in Twinned River Basins. RIVERTWIN, Tashkent, SIC ICWC, 188.

Mannig, B., Müller, M., Starke, E., Merkenschlager, C., Mao C, W., Zhi, X., Podzun, R., Jacob, D., \& Paeth, H. (2013). Dynamical downscaling of climate change in Central Asia. Global and Planetary Change, 110, 26-39. https://doi.org/10.1016/j.gloplacha.2013.05.008

Parry, M. L., Consiam, O., Palutikof, G. P., Linden, P. J., \& Hansen, E. C. (2007). Climate change 2007: impacts, adaptation and vulnerability. Contribution WG2 to the Fourth Assessment report to Intergovernmental panel of climate changes, Edition Cambridge University press, Cambridge, UK, 469-506. https://doi.org/10.1016/S0959-3780(99)00018-7

Parry, M. L., Rozenzweig, C., Iglesias, F., Fisher, G., \& Livermore, G. (1999). Climate changes and world food security. Global environment, 9, 51-67.

Rozenzweig, C., Iglesias, A., Yang, V. B., Epshtein, P. Z., \& Chevian, E. (2001). Climate change and extreme weather events: implication for food production, plant diseases and pest. Global change and human health, 2, 90-104. https://doi.org/10.1023/A:1015086831467

Stulina, G., \& Madramootoo, C. (2005). Adaptation Water Resources Management to climate change condition in Aral Sea Basin, Alberta.

Stulina, G. V., \& Solodkiy, G. F. (2011). Adaptation of water planning to climatic and hydrogeological changes: the use of water and land resources and environmental problems in the EECCA region in context of climate change. Collection of scientific papers, SIC ICWC, Tashkent, 46-59.

Stulina, G., \& Usmanov, V. (2002). What is to expert in agriculture in view of climate change. Dialogue on water and climate: Aral Sea Basin case study, Project N 12.130.021, Tashkent.

Vleck, P. L. G., Rodrigez, K. G., \& Sommer, R. (2004). Energy use and $\mathrm{CO}_{2}$ production in tropical agriculture and means and strategies for reduction or mitigation. Environment, development and sustainability, 6 , 213-233. https://doi.org/10.1023/B:ENVI.0000003638.42750.36

\section{Copyrights}

Copyright for this article is retained by the author(s), with first publication rights granted to the journal.

This is an open-access article distributed under the terms and conditions of the Creative Commons Attribution license (http://creativecommons.org/licenses/by/3.0/). 